Note

\title{
Kocuria polaris sp. nov., an orange-pigmented psychrophilic bacterium isolated from an Antarctic cyanobacterial mat sample
}

\author{
Gundlapally S. N. Reddy, ${ }^{1}$ Jogadhenu S. S. Prakash, ${ }^{1}$ Vadivel Prabahar, ${ }^{1}$ \\ Genki I. Matsumoto, ${ }^{2}$ Erko Stackebrandt ${ }^{3}$ and Sisinthy Shivaji ${ }^{1}$ \\ ${ }^{1}$ Centre for Cellular and Molecular Biology, Uppal Road, Hyderabad 500 007, India
${ }^{2}$ Department of Environmental and Information Science, Otsuma Women's University, Tamashi, Tokyo 206, Japan
${ }^{3}$ Deutsche Sammlung von Mikroorganismen und Zellkulturen (DSMZ), Mascheroder Weg $1 \mathrm{~b}$, D-38124 Braunschweig, Germany

Correspondence

Sisinthy Shivaji

shivas@ccmb.res.in

\begin{abstract}
Strain CMS 76 or $^{\top}$, an orange-pigmented bacterium, was isolated from a cyanobacterial mat sample from a pond located in McMurdo Dry Valley, Antarctica. On the basis of chemotaxonomic and phylogenetic properties, strain CMS $76 \mathrm{or}^{\top}$ was identified as a member of the genus Kocuria. It exhibited a $16 \mathrm{~S}$ rDNA similarity of $99.8 \%$ and DNA-DNA similarity of $71 \%$ with Kocuria rosea (ATCC $186^{\top}$ ). Phenotypic traits confirmed that strain CMS 76 or $^{\top}$ and $K$. rosea were well differentiated. Furthermore, strain CMS $76 \mathrm{or}^{\top}$ could be differentiated from the other reported species of Kocuria, namely Kocuria kristinae (ATCC $27570^{\top}$ ), Kocuria varians (ATCC $15306^{\top}$ ), Kocuria rhizophila (DSM 11926 ${ }^{\top}$ ) and Kocuria palustris (DSM 11025 ${ }^{\top}$ ), on the basis of a number of phenotypic features. Therefore, it is proposed that strain CMS $76 \mathrm{or}^{\top}\left(=\mathrm{MTCC}^{\top} 3702^{\top}=\mathrm{DSM}\right.$ $14382^{\top}$ ) be assigned to a novel species of the genus Kocuria, as Kocuria polaris.
\end{abstract}

The genus Kocuria was created from the genus Micrococcus on the basis of the phylogenetic and chemotaxonomic dissection of the genus Micrococcus (Stackebrandt et al., 1995). At the time of writing, the genus Kocuria contained five species, i.e. Kocuria rosea, Kocuria varians, Kocuria kristinae, Kocuria palustris and Kocuria rhizophila. All of the recognized species of Kocuria are coccoid, Gram-positive, non-endospore-forming, aerobic, non-halophilic microorganisms that can be differentiated from other genera in the order Actinomycetales on the basis of their peptidoglycan type (L-Lys-Ala $\mathrm{Al}_{3 / 4}$ ), the presence of galactosamine and glucosamine as their major cell-wall amino sugars, the presence of MK-7 $\left(\mathrm{H}_{2}\right)$ and $\mathrm{MK}-8\left(\mathrm{H}_{2}\right)$ as their major menaquinones, the presence of diphosphatidylglycerol and phosphatidylglycerol, the presence of the fatty acid anteiso- $\mathrm{C}_{15: 0}$ and the $\mathrm{G}+\mathrm{C}$ content of their DNA, which ranges from 66 to $75 \mathrm{~mol} \%$. In addition, all of the reported species have been observed to be mesophilic (Stackebrandt et al., 1995). In the present study, a psychrophilic bacterium

Published online ahead of print on 28 June 2002 as DOI 10.1099/ ijs.0.02336-0

Abbreviation: ABM, Antarctic bacterial medium.

The EMBL accession number for the 16S rDNA sequence of Kocuria polaris CMS 76 or $^{\top}$ is AJ278868.

Pigment characteristics of strain CMS $76 \mathrm{or}^{\top}$ are available as supplementary data in IJSEM Online (http://ijs.sgmjournals.org). (strain CMS 76or ${ }^{\mathrm{T}}$ ) isolated from a cyanobacterial mat sample originating from a pond in Antarctica was identified as a novel species of the genus Kocuria on the basis of its morphological, chemotaxonomic and phylogenetic properties. We propose the name Kocuria polaris for this novel species.

Strain CMS 76 or $^{\mathrm{T}}$ was isolated from a cyanobacterial mat sample (predominantly containing Phormidium sp.) collected from pond L9 $\left(77^{\circ} 33^{\prime} 3^{\prime \prime} \mathrm{S}, 160^{\circ} 38^{\prime} \mathrm{E}\right)$ located in Wright Valley, McMurdo, Antarctica (Matsumoto, 1993). The mat sample $(200 \mathrm{mg}$ ) was processed, plated onto Antarctic bacterial medium (ABM) plates containing $0.5 \%$ $(\mathrm{w} / \mathrm{v})$ peptone, $0.2 \%(\mathrm{w} / \mathrm{v})$ yeast extract and $1.5 \%(\mathrm{w} / \mathrm{v})$ agar ( $\mathrm{pH} 6.9)$ and incubated at $5{ }^{\circ} \mathrm{C}$ (Shivaji et al., 1992) for 15 days. The colonies that appeared were predominantly white in colour, except those of strains CMS 76 or $^{\mathrm{T}}$ and CMS $90 \mathrm{r}^{\mathrm{T}}$, which were orange ('or' suffix) and red (' $r$ ' suffix), respectively. Strain CMS $90 \mathrm{r}^{\mathrm{T}}$ has subsequently been described as Arthrobacter roseus (Reddy et al., 2002a).

The shape and motility of cultures from the lag, exponential and stationary phases of growth were observed by phasecontrast microscopy (magnification, $\times 1000$ ). Motility was determined by the hanging drop method, and staining of the flagellum was done by the silver impregnation method (Blenden \& Goldberg, 1965). All enzyme tests were performed by growing strains at $20^{\circ} \mathrm{C}$ in the appropriate 
medium according to standard methods (Holding \& Collee, 1971). The production of indole, the methyl red test, the Voges-Proskauer test, levan formation, reduction of nitrate to nitrite, hydrolysis of starch and aesculin, and the formation of acid and gas were also monitored according to standard methods (Hugh \& Leifson, 1953; Stanier et al., 1966; Holding \& Collee, 1971; Stolp \& Gadkari, 1981). The abilities of strain CMS $76 \mathrm{or}^{\mathrm{T}}, K$. rosea ATCC $186^{\mathrm{T}}$ and K. rosea ATCC 187 (formerly the type strain of Kocuria erythromyxa) to utilize various carbon compounds as sole carbon sources were tested using minimal medium $[1.05 \%$ $\mathrm{K}_{2} \mathrm{HPO}_{4}, 0 \cdot 45 \% \mathrm{KH}_{2} \mathrm{PO}_{4}, 0 \cdot 1 \%\left(\mathrm{NH}_{4}\right)_{2} \mathrm{SO}_{4}, 0 \cdot 5 \%$ carbon source]. Determinations of sensitivity to different antibiotics and of the optimal temperature, $\mathrm{pH}$ and salt values for growth were done on ABM plates. K. rosea ATCC $186^{\mathrm{T}}$, K. rosea ATCC 187 and Sphingobacterium antarcticum ATCC $51969^{\mathrm{T}}$ were used as controls in this study.

The phenotypic properties of strain CMS 76or ${ }^{\mathrm{T}}$ are given in the species description for $K$. polaris. Characteristics useful for distinguishing strain CMS 76 or $^{\mathrm{T}}$ from its closest relatives are listed in Tables 1 and 2.

The 16S rRNA gene of strain CMS 76or ${ }^{\mathrm{T}}$ was amplified and sequenced as described previously (Shivaji et al., 2000). The almost-complete 16S rDNA sequence of strain CMS $76 \mathrm{or}^{\mathrm{T}}$ (1451 nt) was aligned with 14 reference sequences deposited in EMBL, using CLUSTAL V (Higgins et al., 1992). Furthermore, following an initial crude taxonomic affiliation, a more-detailed analysis was done using the $16 \mathrm{~S}$ rDNA sequences of members of the genera Kocuria, Micrococcus, Nesterenkonia, Dermacoccus and Renibacterium. The DNADIST program with the Kimura-2 correction model (Kimura, 1980) was used to compute the pairwise evolutionary distances from the aligned sequences. To obtain the confidence values for the 16S-rDNA-based genetic affiliations, the original sequence dataset was resampled 1000 times using SEQBOOT and subjected to bootstrap analysis. Phylogenetic trees were constructed using parsimony analysis (DNAPARS) and clustering algorithms such as FITCH, KITCH and the UPGMA linkage algorithm (Felsenstein, 1993). The different algorithms gave consistent results.

On the basis of $16 \mathrm{~S}$ rDNA sequence similarity values, strain CMS 76or ${ }^{\mathrm{T}}$ was most closely related to members of the genus Kocuria $(96 \cdot 1-99 \cdot 8 \%$ similarity) and exhibited highest similarity values with the sequence of the type strain of $K$. rosea $(99 \cdot 8 \%)$. In the 16S-rDNA-based phylogenetic tree (Fig. 1), strain CMS 76or ${ }^{\mathrm{T}}$ was observed to be positioned closest to $K$. rosea DSM $20447^{\mathrm{T}}$. The statistical significance of this lineage was high (bootstrap value, $100 \%$ ). It was observed that the overall genomic relatedness between strains CMS 76or ${ }^{\mathrm{T}}$ and $K$. rosea ATCC $186^{\mathrm{T}}$, based on DNA-DNA hybridization performed using the membrane filter method (Reddy et al., 2000b), was $71 \%$.

Determinations of the type of peptidoglycan (Rosenthal \& Dziarski, 1994), the fatty acid composition (Sato \& Murata,
1988), the types of menaquinone (Collins et al., 1977; Dunphy et al., 1971), the polar lipids and the cell-wall sugars were done according to standard methods, as described previously (Komagata \& Suzuki, 1987). Furthermore, pigments were extracted from lyophilized bacterial cell pellets, separated by TLC, and the absorption spectra of the individual pigments were recorded using a Hitachi 2000 spectrophotometer (Jagannadham et al., 1991). The G+C content $(\mathrm{mol} \%)$ of the DNA of strain CMS $76 \mathrm{or}^{\mathrm{T}}$ was determined as described previously (Reddy et al., 2000).

The affiliation of strain CMS $76 \mathrm{or}^{\mathrm{T}}$ with the genus Kocuria was further supported by its chemotaxonomic properties, since in strain CMS 76or ${ }^{\mathrm{T}}$, as in other species of the genus Kocuria, the peptidoglycan present was L-Lys- $\mathrm{Ala}_{3}$, of the A3 $\alpha$ peptidoglycan type. MK-7 $\left(\mathrm{H}_{2}\right)(48 \%)$ and MK- $8\left(\mathrm{H}_{2}\right)$ $(43 \%)$ were the major menaquinones of strain CMS 76 or $^{\mathrm{T}}$; MK-6 $\left(\mathrm{H}_{2}\right)(5 \cdot 6 \%)$ and MK-9 $\left(\mathrm{H}_{2}\right)(3 \cdot 4 \%)$ were the minor menaquinones. The major fatty acid was anteiso- $\mathrm{C}_{15: 0}$ $(70 \cdot 6 \%)$. Phosphatidylglycerol, diphosphatidylglycerol (cardiolipin), phosphatidylinositol and an unidentified phospholipid were the polar lipids of strain CMS $76 \mathrm{or}^{\mathrm{T}}$. The DNA G+C content of strain CMS $76 \mathrm{or}^{\mathrm{T}}$ was $72.5 \mathrm{~mol} \%$ (Tables 1 and 2). Strain CMS 76or ${ }^{\mathrm{T}}$ also contained six carotenoid pigments (with $R_{\mathrm{F}}$ values of $0 \cdot 92,0 \cdot 78$, $0 \cdot 61,0.53,0.46$ and 0.32 , respectively). Pigment characteristics of strain CMS $76 \mathrm{or}^{\mathrm{T}}$ are available as supplementary data in IJSEM Online (http://ijs.sgmjournals.org).

Strain CMS 76or ${ }^{\mathrm{T}}$, like other species of the genus Kocuria, was an aerobic, non-halophilic, catalase-positive, indolenegative micro-organism that was sensitive to penicillin, chloramphenicol, ampicillin and erythromycin (Schleifer, 1986; Rainey et al., 1997; Stackebrandt et al., 1995; Kovács et al., 1999). Furthermore, the chemotaxonomic characteristics of the strain and the topology of the 16S-rDNA-based phylogenetic tree (Fig. 1) clearly indicated that strain CMS $76 \mathrm{or}^{\mathrm{T}}$ was a member of the genus Kocuria. At the 16S rDNA level, strain CMS 76or ${ }^{\mathrm{T}}$ was closely related to all species of the genus Kocuria $(96 \cdot 1-99 \cdot 8 \%$ similarity), and exhibited maximum similarity with the $16 \mathrm{~S}$ rDNA sequence of $K$. rosea ATCC $186^{\mathrm{T}}$. DNA-DNA hybridization data for strain CMS $76 \mathrm{or}^{\mathrm{T}}$ and K. rosea ATCC $186^{\mathrm{T}}$ indicated $71 \%$ similarity between the two strains. Despite the similarity at the DNA level between the novel strain and $K$. rosea ATCC $186^{\mathrm{T}}$, strain CMS 76or ${ }^{\mathrm{T}}$ differed from K. rosea ATCC $186^{\mathrm{T}}$, and from K. kristinae (ATCC $186^{\mathrm{T}}$ ), K. varians (ATCC $15306^{\mathrm{T}}$ ), K. rhizophila (DSM $11926^{\mathrm{T}}$ ) and K. palustris (DSM $11025^{\mathrm{T}}$ ), with respect to the following five phenotypic features: its ability to grow at $5^{\circ} \mathrm{C}$; its inability to grow in the presence of $5 \% \mathrm{NaCl}$; its production of acid from D-mannitol and D-xylose; its high DNA G $+\mathrm{C}$ content $(72.5 \mathrm{~mol} \%)$ (Table 1). In addition to the above five differences, strain CMS 76or ${ }^{\mathrm{T}}$ differed from $K$. rosea ATCC $186^{\mathrm{T}}$ and $K$. rosea ATCC 187 in that it formed extremely mucoid colonies on ABM plates, produced acid from D-glucose and D-mannitol, and could utilize adonitol, D-melibiose, D-cellobiose, meso-inositol, lactose, pyruvate, inulin, 
Table 1. Phenotypic characteristics useful for differentiating strain CMS 76 or $^{\top}$ from Kocuria spp.

Strain: 1, CMS 76 or $^{\mathrm{T}}$; 2, K. rosea ATCC $186^{\mathrm{T}}$; 3, K. rosea ATCC 187; 4, K. varians ATCC 15306 ${ }^{\mathrm{T}}$; 5 , K. kristinae ATCC $27570^{\mathrm{T}}$; 6, K. palustris ATCC $11925^{\mathrm{T}} ; 7$, K. rhizophila DSM $11926^{\mathrm{T}}$. NA, Data not available; ND, not done. +, Positive; -, negative; $(+)$, weakly positive. K. rosea ATCC 187 was previously known as the type species of K. erythromyxa.

\begin{tabular}{|c|c|c|c|c|c|c|c|}
\hline Characteristic & $1^{\star}$ & $2^{\star}$ & $3^{*} \dagger$ & $4 \ddagger$ & $5 \ddagger$ & $6 \S$ & $7 \S$ \\
\hline \multicolumn{8}{|l|}{ Growth at: } \\
\hline $37^{\circ} \mathrm{C}$ & - & + & + & + & + & - & + \\
\hline Growth in $5 \% \mathrm{NaCl}$ & - & + & + & + & + & $(+)$ & + \\
\hline \multicolumn{8}{|c|}{ Acid (produced aerobically) from: } \\
\hline D-Mannose & - & - & - & - & + & - & + \\
\hline D-Mannitol & + & - & - & - & - & - & - \\
\hline L-Rhamnose & + & - & + & - & - & - & - \\
\hline D-Xylose & + & - & - & + & - & - & - \\
\hline Aesculin hydrolysis & - & - & - & - & + & - & - \\
\hline Phosphatase & - & - & - & - & - & - & + \\
\hline Nitrate reduction & + & + & + & + & - & + & - \\
\hline \multicolumn{8}{|l|}{ Utilization of carbon source: } \\
\hline D-Maltose & + & - & + & + & + & - & - \\
\hline Adonitol & + & - & - & + & + & + & + \\
\hline D-Mellibiose & + & - & - & + & - & - & - \\
\hline L-Arabinose & - & - & - & + & + & - & + \\
\hline L-Alanine & - & - & - & - & + & - & - \\
\hline D-Cellobiose & $(+)$ & - & - & NA & NA & - & - \\
\hline meso-Inositol & + & - & - & NA & NA & NA & NA \\
\hline Lactose & + & - & - & NA & NA & NA & NA \\
\hline L-Aspargine & - & + & + & NA & NA & $\mathrm{NA}$ & NA \\
\hline L-Glutamic acid & $(+)$ & - & + & - & + & - & - \\
\hline L-Leucine & + & - & - & NA & NA & NA & NA \\
\hline L-Phenylalanine & + & - & - & $\mathrm{NA}$ & NA & $\mathrm{NA}$ & NA \\
\hline \multicolumn{8}{|l|}{ Fermentation of sugar: } \\
\hline Lactose & + & - & - & NA & NA & $\mathrm{NA}$ & NA \\
\hline Sucrose & + & - & - & NA & NA & NA & NA \\
\hline \multirow[t]{4}{*}{ Menaquinones } & MK-6 $\left(\mathrm{H}_{2}\right)$, & MK-7 $\left(\mathrm{H}_{2}\right) \ddagger$ & MK-6 $\left(\mathrm{H}_{2}\right)$ & MK-7 $\left(\mathrm{H}_{2}\right)$, & $\operatorname{MK}-7\left(\mathrm{H}_{2}\right)$, & MK-6 $\left(\mathrm{H}_{2}\right)$, & MK-6( $\left.\mathrm{H}_{2}\right)$, \\
\hline & $\operatorname{MK}-7\left(\mathrm{H}_{2}\right)$ & $\mathrm{MK}-8\left(\mathrm{H}_{2}\right)$ & MK-7 $\left(\mathrm{H}_{2}\right)$ & MK-8 $\left(\mathrm{H}_{2}\right)$ & MK-8 $\left(\mathrm{H}_{2}\right)$ & MK-7 $\left(\mathrm{H}_{2}\right)$, & $\mathrm{MK}-7\left(\mathrm{H}_{2}\right)$, \\
\hline & MK-8 $\left(\mathrm{H}_{2}\right)$, & MK-9 $\left(\mathrm{H}_{2}\right)$ & MK-8 $\left(\mathrm{H}_{2}\right)$ & & & $\mathrm{MK}-8\left(\mathrm{H}_{2}\right)$ & $\mathrm{MK}-8\left(\mathrm{H}_{2}\right)$, \\
\hline & MK- $9\left(\mathrm{H}_{2}\right)$ & & MK-9 $\left(\mathrm{H}_{2}\right)$ & & & & $\mathrm{MK}-9\left(\mathrm{H}_{2}\right)$ \\
\hline DNA G $+\mathrm{C}$ content $(\mathrm{mol} \%)$ & $72 \cdot 5$ & $66-75 \dagger$ & 71 & $66-72$ & 67 & $69 \cdot 6$ & $69 \cdot 4$ \\
\hline
\end{tabular}

${ }^{*}$ Data acquired in the present study.

†G + C data were taken from Brooks et al. (1980) and menaquinone data from Rainey et al. (1997).

‡Data from Stackebrandt et al. (1995).

$\S$ Data from Kovács et al. (1999). 
Table 2. Fatty acid compositions of $K$. rosea ATCC $186^{\top}$ and strain CMS 76 or $^{\top}$

Both strains were cultured in $\mathrm{ABM}$ at $22^{\circ} \mathrm{C}$.

\begin{tabular}{|c|c|c|}
\hline \multirow[t]{2}{*}{ Fatty acid } & \multicolumn{2}{|c|}{ Fatty acid (percentage of total fatty acids) } \\
\hline & K. rosea ATCC $186^{\mathrm{T}}$ & CMS 76or ${ }^{T}$ \\
\hline iso- $\mathrm{C}_{14: 0}$ & $1 \cdot 3$ & $0 \cdot 7$ \\
\hline $\mathrm{C}_{14: 0}$ & $0 \cdot 5$ & $1 \cdot 1$ \\
\hline iso- $\mathrm{C}_{15: 0}$ & $5 \cdot 1$ & $3 \cdot 2$ \\
\hline anteiso- $\mathrm{C}_{15: 0}$ & $65 \cdot 0$ & $70 \cdot 6$ \\
\hline $\mathrm{C}_{15: 0}$ & $0 \cdot 8$ & $0 \cdot 6$ \\
\hline iso- $\mathrm{C}_{16: 0}$ & $3 \cdot 0$ & $0 \cdot 9$ \\
\hline $\mathrm{C}_{16: 0}$ & $3 \cdot 2$ & $2 \cdot 4$ \\
\hline $\mathrm{C}_{16: 1}$ & $3 \cdot 5$ & $2 \cdot 2$ \\
\hline iso- $\mathrm{C}_{17: 0}$ & $1 \cdot 5$ & $2 \cdot 9$ \\
\hline anteiso- $\mathrm{C}_{17: 0}$ & $7 \cdot 1$ & $5 \cdot 6$ \\
\hline anteiso- $\mathrm{C}_{17: 1}$ & $5 \cdot 0$ & $4 \cdot 8$ \\
\hline iso- $\mathrm{C}_{18: 0}$ & $0 \cdot 9$ & $3 \cdot 0$ \\
\hline $\mathrm{C}_{18: 0}$ & $2 \cdot 9$ & $1 \cdot 2$ \\
\hline $\mathrm{C}_{18: 1}$ & - & $0 \cdot 9$ \\
\hline
\end{tabular}

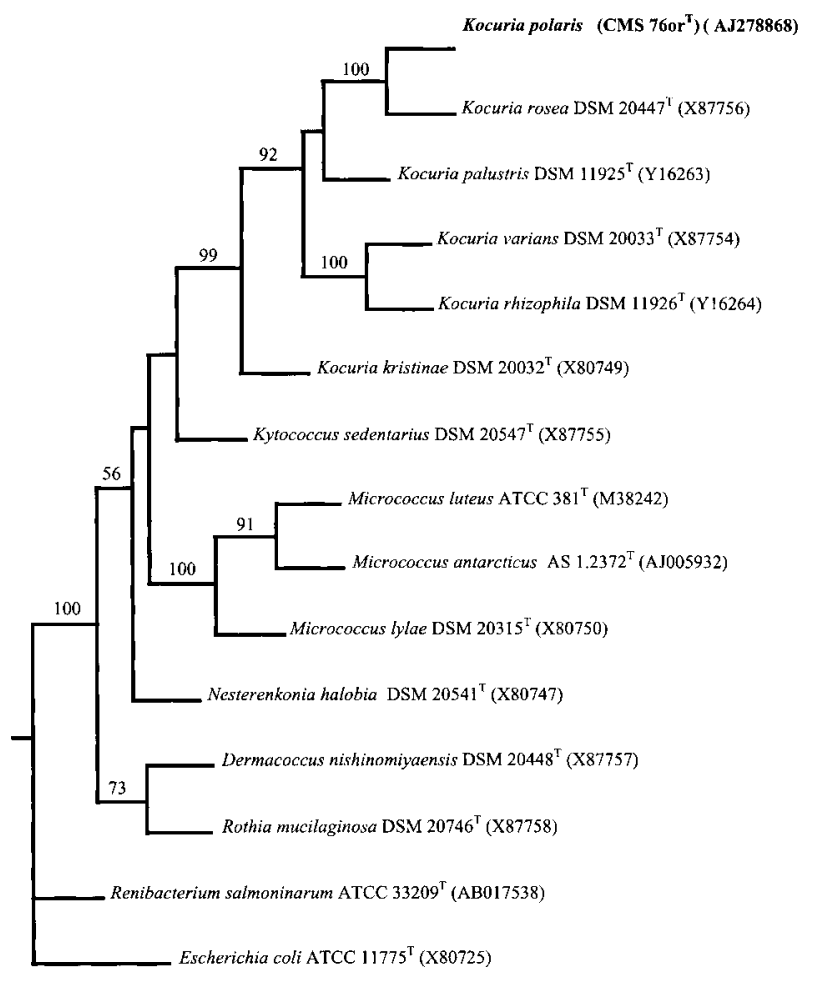

Fig. 1. Phylogenetic relationship of strain CMS 76 or $^{\top}$ with related species of the genera Kocuria, Micrococcus, Dermacoccus and Nesterenkonia, based on the 16S rDNA sequence analysis done using DNAPARS. Escherichia coli was used to root the tree. The bootstrap values (expressed as percentages) are given at the nodes. Branch lengths indicated in the tree are not to scale.
D-raffinose, L-arginine, L-aspartic acid, L-glutamic acid, L-leucine or L-phenylalanine as the sole carbon source. It was unable to utilize L-aspargine as the sole carbon source, but could ferment lactose and sucrose (Table 1). Furthermore, it was observed that in strain CMS 76 or $^{\mathrm{T}}$ six carotenoid pigments were present, whereas in $K$. rosea ATCC $186^{\mathrm{T}}$ only five pigments were present (supplementary data; http://ijs.sgmjournals.org). It was also observed in the present study that the type strain of $K$. rosea (ATCC $186^{\mathrm{T}}$ ) had MK-7 $\left(\mathrm{H}_{2}\right)(33 \cdot 4 \%)$ and MK-8 $\left(\mathrm{H}_{2}\right)(61 \cdot 0 \%)$ as its major menaquinones, with MK- $9\left(\mathrm{H}_{2}\right)(5 \cdot 6 \%)$ as a minor component. In contrast, strain CMS 76 or $^{\mathrm{T}}$ had MK-7 $\left(\mathrm{H}_{2}\right)$ $(48 \%)$ and $\mathrm{MK}-8\left(\mathrm{H}_{2}\right)(43 \%)$ as its major menaquinones and, in addition, small amounts of MK-6 $\left(\mathrm{H}_{2}\right)(5 \cdot 5 \%)$ and MK-9 $\left(\mathrm{H}_{2}\right)(3 \cdot 4 \%)$ (Table 1). It was also observed that when K. rosea ATCC $186^{\mathrm{T}}$ and strain CMS 76or ${ }^{\mathrm{T}}$ were cultured in $\mathrm{ABM}$ they exhibited distinct quantitative differences in their fatty acid compositions. For instance, in strain CMS $76 \mathrm{or}^{\mathrm{T}}$, iso- $\mathrm{C}_{14: 0}$, iso- $\mathrm{C}_{16: 0}$ and $\mathrm{C}_{18: 0}$ were decreased relative to K. rosea ATCC $186^{\mathrm{T}}$, whereas $\mathrm{C}_{14: 0}$, iso- $\mathrm{C}_{17: 0}$ and iso- $\mathrm{C}_{18: 0}$ were increased and $\mathrm{C}_{18: 1}$ was also present (Table 2). Strain CMS 76 or $^{\mathrm{T}}$ could also be differentiated from the other species of Kocuria on the basis of some of its phenotypic characteristics (Table 1). Thus, on the basis of the similarities of strain CMS 76 or $^{\mathrm{T}}$ with respect to the generic characteristics of the genus Kocuria, and its distinct differences with respect to all recognized species of Kocuria, it is proposed that strain CMS 76 or $^{\mathrm{T}}$ be assigned to a novel species of the genus Kocuria, as Kocuria polaris.

\section{Description of Kocuria polaris sp. nov.}

Kocuria polaris (po.la' ris. M.L. adj. polaris of, or pertaining to, a pole).

Cells are coccoid $(1 \cdot 0-1 \cdot 5 \mu \mathrm{m}$ in diameter), occurring in pairs, tetrads or clusters. Non-motile, Gram-positive and aerobic. Colonies on peptone/yeast extract medium are $0 \cdot 1-2 \cdot 0 \mathrm{~mm}$ in diameter and appear smooth, round, uniformly edged, translucent, mucoid and orange in colour. Psychrophilic. Grows between 5 and $30^{\circ} \mathrm{C}$, with optimum growth at $20^{\circ} \mathrm{C}$. Grows in $\mathrm{ABM}$ adjusted to $\mathrm{pH} 7-12$ and tolerates up to $2.9 \% \mathrm{NaCl}$. Catalase- and lipase-positive. Negative for L-lysine decarboxylase, L-arginine decarboxylase, $\beta$-galactosidase, L-arginine dihydrolase and levan formation. Negative results in the indole test, the methyl red test and the Voges-Proskauer test. Utilizes L-rhamnose, D-cellobiose, D-fructose, D-galactose, D-glucose, glycerol, D-mannose, D-xylose, acetate, sorbitol, L-glutamine, L-glycine, L-serine and L-threonine as sole carbon sources, but can not utilize meso-erythritol, melezitose, D-ribose, D-sorbose, citrate, dextran, lactic acid, dulcitol, sucrose, succinic acid, thioglycollate, D-trehalose, L-cysteine, L-histidine, L-isoleucine, L-lysine, L-proline, L-methionine, L-tyrosine, L-tryptophan, L-valine or $\beta$-hydroxybutyric acid as sole carbon sources. Does not produce gas from D-glucose, D-fructose, L-arabinose, D-xylose, L-rhamnose, D-galactose, D-mannose, D-mannitol, lactose or sucrose. Acid is produced in the presence of D-fructose, D-galactose, 
lactose and sucrose. Oxidizes D-glucose, D-maltose, D-ribose, D-trehalose and D-xylose, but not L-arabinose or D-galactose. Ferments D-fructose, but not L-arabinose, D-galactose, D-glucose, D-maltose, D-ribose, D-trehalose or D-xylose. Other characteristics of the species can be found in Table 1. Sensitive to ampicillin, cefoperazone, co-trimoxazole, amikacin, cefazoline, ciprofloxacin, penicillin, vancomycin, tetracycline, lomefloxacin, erythromycin, roxithromycin, tobramycin, cephotaxime, lincomycin, chloramphenicol, streptomycin, kanamycin, norfloxacin, amoxycillin and cefuroxime, but resistant to nitrofurantoin, nalidixic acid and colistin. Cell-wall peptidoglycan is L-Lys-Ala 3 (type A3 $\alpha$ ). D-Galactose, D-glucose and D-ribose are the major cell-wall sugars. Menaquinones and fatty acid composition of the species are shown in Tables 1 and 2, respectively. Polar lipids are phosphatidylglycerol, diphosphatidylglycerol, phosphatidylinositol and an unidentified phospholipid. Cells contain six water-insoluble pigments that are soluble in methanol; pigment production is not dependent on any specific growth conditions or on the composition of the medium. DNA G+C content is $72.5 \mathrm{~mol} \%$. Isolated from a cyanobacterial mat sample from McMurdo Dry Valley, Antarctica $\left(77^{\circ} 33^{\prime} 3^{\prime \prime} S\right.$, $\left.160^{\circ} 38^{\prime} \mathrm{E}\right)$. The type strain is CMS $76 \mathrm{or}^{\mathrm{T}}\left(=\mathrm{MTCC} 3702^{\mathrm{T}}\right.$ $=$ DSM $14382^{\mathrm{T}}$ ).

\section{Acknowledgements}

This work was supported by a grant from the Department of Biotechnology, Government of India.

\section{References}

Blenden, D. C. \& Goldberg, M. S. (1965). Silver impregnation stain for Leptospira and flagella. J Bacteriol 89, 899-900.

Brooks, B. W., Murray, R. G. E., Johnson, J. L., Stackebrandt, E., Woese, C. R. \& Fox, G. E. (1980). Red-pigmented micrococci: a basis for taxonomy. Int J Syst Bacteriol 30, 627-646.

Collins, M. D., Pirouz, T., Goodfellow, M. \& Minnikin, D. E. (1977). Distribution of menaquinones in actinomycetes and corynebacteria. J Gen Microbiol 100, 221-230.

Dunphy, P. J., Phillips, P. G. \& Brodie, A. F. (1971). Separation and identification of menaquinones from microorganisms. J Lipid Res 12, 442-449.

Felsenstein, J. (1993). PHYLIP (phylogeny inference package), version 3.5c. Department of Genetics, University of Washington, Seattle, USA.

Holding, A. J. \& Collee, J. G. (1971). Routine biochemical tests. Methods Microbiol 6A, 2-32.

Higgins, D. G., Bleasby, A. J. \& Fuchs, R. (1992). CLUSTAL V: improved software for multiple sequence alignment. Comput Appl Biosci 8, 189-191.

Hugh, R. \& Leifson, E. (1953). The taxonomic significance of fermentative versus oxidative metabolism of carbohydrates by various gram-negative bacteria. J Bacteriol 66, 24-26.

Jagannadham, M. V., Rao, V. J. \& Shivaji, S. (1991). The major carotenoid pigment of a psychrotrophic Micrococcus roseus: purification, structure, and interaction of the pigment with synthetic membranes. J Bacteriol 173, 7911-7917.

Kimura, M. (1980). A simple method for estimating evolutionary rates of base substitutions through comparative studies of nucleotide sequences. J Mol Evol 16, 111-120.

Komagata, K. \& Suzuki, K. I. (1987). Lipid and cell wall analysis in bacterial systematics. Methods Microbiol 19, 161-206.

Kovács, G., Burghardt, J., Pradella, S., Schumann, P., Stackebrandt, E. \& Màrialigeti, K. (1999). Kocuria palustris sp. nov. and Kocuria rhizophila sp. nov., isolated from the rhizoplane of the narrow-leaved cattail (Typha angustifolia). Int J Syst Bacteriol 49, 167-173.

Matsumoto, G. I. (1993). Geochemical features of the McMurdo Dry Valley lakes, Antarctica. Physical and biogeochemical processes in Antarctic lakes. Antarct Res Ser 49, 95-118.

Rainey, F. A., Nobre, M. F., Schumann, P., Stackebrandt, E. \& da Costa, M. S. (1997). Phylogenetic diversity of the Deinococci as determined by $16 \mathrm{~S}$ ribosomal DNA sequence comparison. Int J Syst Bacteriol 47, 510-514.

Reddy, G. S. N., Aggarwal, R. K., Matsumoto, G. I. \& Shivaji, S. (2000). Arthrobacter flavus sp. nov., a psychrophilic bacterium isolated from a pond in McMurdo Dry Valley, Antarctica. Int J Syst Evol Microbiol 50, 1553-1561.

Reddy, G. S. N., Prakash, J. S. S., Matsumoto, G. I., Stackebrandt, E. \& Shivaji, S. (2002a). Arthrobacter roseus sp. nov., a psychrophilic bacterium isolated from an Antarctic cyanobacterial mat sample. Int J Syst Evol Microbiol 52, 1017-1021.

Reddy, G. S. N., Prakash, J. S. S., Vairamani, M., Prabhakar, S., Matsumoto, G. I. \& Shivaji, S. (2002b). Planococcus antarcticus and Planococcus psychrophilus spp. nov. isolated from cyanobacterial mat samples collected from ponds in Antarctica. Extremophiles 6, 253-261.

Rosenthal, R. S. \& Dziarski, R. (1994). Isolation of peptidoglycan and soluble peptidoglycan fragment. Methods Enzymol 235, 253-285.

Sato, N. S. \& Murata, N. (1988). Membrane lipids. Methods Enzymol 167, 251-259.

Schleifer, K. H. (1986). Family I. Micrococcaceae Prevot 1961, $31^{\mathrm{AL}}$. In Bergey's Manual of Systematic Bacteriology, vol. 2, pp. 1003-1008. Edited by P. H. A. Sneath, N. S. Mair, M. E. Sharpe \& J. G. Holt. Baltimore: Williams \& Wilkins.

Shivaji, S., Ray, M. K., Rao, N. S., Saisree, L., Jagannadham, M. V., Kumar, G. S., Reddy, G. S. N. \& Bhargava, P. M. (1992). Sphingobacterium antarcticus sp. nov., a psychrotrophic bacterium from the soils of Schirmacher Oasis, Antarctica. Int J Syst Bacteriol 42, 102-106.

Shivaji, S., Bhanu, N. V. \& Aggarwal, R. K. (2000). Identification of Yersinia pestis as the causative organism of Plague in India as determined by $16 \mathrm{~S}$ rDNA sequencing and RAPD-based genomic fingerprinting. FEMS Microbiol Lett 189, 247-252.

Stackebrandt, E., Koch, C., Gvozdiak, O. \& Schumann, P. (1995). Taxonomic dissection of the genus Micrococcus: Kocuria gen. nov., Nesterenkonia gen. nov., Kytococcus gen. nov., Dermacoccus gen. nov., and Micrococcus Cohn 1872 gen. emend. Int J Syst Bacteriol 45, 682-692.

Stanier, R. Y., Palleroni, N. J. \& Doudoroff, M. (1966). The aerobic pseudomonads: a taxonomic study. J Gen Microbiol 43, 159-271.

Stolp, H. \& Gadkari, D. (1981). Nonpathogenic members of the genus Pseudomonas. In The Prokaryotes, vol. 1, pp. 719-741. Edited by M. P. Starr, H. Stolp, H. G. Trüper, A. Balows \& H. G. Schlegel. Berlin: Springer-Verlag. 